\title{
Closed Loop Control of Bi-Directional Soft Switched Quasi Z-Source DC-DC Converter
}

\author{
A. Suresh1", M. R. Rashmi2, V. Madusuthanan'2, P. Vinoth Kumar1 \\ ${ }^{1}$ Department of Electrical and Electronics Engineering, S.A. Engineering College, Chennai, India \\ ${ }^{2}$ Department of EEE, Amrita School of Engineering, Amrita Vishwa Vidyapeetham, Bengaluru, India \\ Email: *drsuresha@saec.ac.in, rashmi.power@gmail.com, madu.2791@gmail.com, vinothkumarktp@gmail.com
}

Received 4 March 2016; accepted 26 April 2016; published 29 April 2016

Copyright (C) 2016 by authors and Scientific Research Publishing Inc.

This work is licensed under the Creative Commons Attribution International License (CC BY).

http://creativecommons.org/licenses/by/4.0/

(c) (i)

\section{Abstract}

Quasi Z-source converter is a single stage soft switched power converter derived from Z-source converter topology, employing an impedance network coupling the source with the converter. The quasi Z-source source converter can buck or boost the voltage and current flow is bidirectional. The duty cycle of the switch can be adjusted to maintain constant voltage during load change. To obtain constant output voltage, proper controller design is a must. This paper presents closed loop control of quasi Z-source converter using PI controller where controller parameters are estimated using the small signal model of the entire system. The transfer function of the system with AC sweep is used to obtain appropriate proportional and integral gain constants to reduce transient dynamics and to reduce steady state error.

\section{Keywords}

Quasi Z-Source Network, PSIM, Soft Switching, Switching Losses, Smart Control, PI Controller Design

\section{Introduction}

Many DC-DC converters can either buck or boost the voltages. The voltage fed converters can only buck the voltage and current fed converters can boost the voltages. There are applications which demands both buck and boost operation, for example battery charging and discharging. During batter charging, the voltage has to be stepped down whereas during battery discharge, the voltage has to be stepped up. The converters which can perform both the operations are Z-source converters which were first proposed by F. Z. Peng [1]. Z-source or impedance source network consists of cross connected L and C elements. Z-source inverters find wide applica-

\footnotetext{
${ }^{*}$ Corresponding author.
}

How to cite this paper: Suresh, A., Rashmi, M.R., Madusuthanan, V. and Kumar, P.V. (2016) Closed Loop Control of Bi-Directional Soft Switched Quasi Z-Source DC-DC Converter. Circuits and Systems, 7, 574-584.

http://dx.doi.org/10.4236/cs.2016.75049 
tions in electric drive systems, as active filters for power quality improvement. The desired AC output can be obtained by controlling the shoot-through duty cycle of the Z-source. The output voltage can also be boosted; therefore Z-source converters can be used to mitigate the voltage sags and also they add on the other benefits like reliability, less harmonics and can have wider range of output voltages [2]-[4].

By controlling the shoot through period, the duty cycle of Z-source converter can be controlled. The Z-source converter can produce any desired output ac voltage, even greater than the line voltage by controlling the shoot through period. Therefore Z-source inverters can be used to compensate the voltages when voltage sag occurs in power systems.

The concept of the Z-source network can be applied to DC-DC power conversion. Z-source dc-dc converter (ZSC) is proposed in [2]. H-bridge has been used to operate in four-quadrant operation for motor drives for many years, but it utilizes four active switches which are expensive and large. Z-source converter for DC motor speed control was proposed in [4]. To improve on the traditional ZSIs, quasi-Z-source inverters (qZSIs), have been developed in [5]. DC-DC switched power converters such as Buck, Boost and Buck/Boost converters have been widely used in industry. They can be divided according to their output characteristics: single-quadrant converters, two-quadrant converters, and four-quadrant converters. Single-quadrant dc-dc converters have been studied for a long time since this type of converter has wide spread applications. Two-quadrant converters also have been discussed in bidirectional current and motor control applications [6]. Four-quadrant converters have been discussed in [7]. The efficiency of multi stage cascaded converter is poor because of losses in every stage. This problem can be overcome in Quadratic converters which was proposed in [8]. The design of Buck, Boost, Buck/Boost, Sepic converters is discussed in [9]-[11]. The four-order converter was taken; both continuous conduction mode and discontinuous conduction mode operations were performed [12]. Along with the advantages of ZSC, qZSC has the above advantages of quasi-Z-source network. Also, the voltage gain of qZSC is the same with that of ZSC. The design of PI controller by using ACSWEEP is discussed in [13] [14]. Quasi Z-source DC-DC converter with switched capacitor was proposed in [15] for higher gain with less voltage stress.

\section{Conventional Z-Source DC-DC Converters}

Z-source network has both the current-fed topology and the voltage-fed topology. This paper focuses on voltage-fed power conversion circuit which is represented in Figure 1. The input part is composed of the input voltage source $V_{\text {in }}$ and the diode $D_{0}$. The Z-source network part is composed of the inductors $L_{1}, L_{2}$ and the capacitors $C_{1}, C_{2}$. The inductors $L_{1}, L_{2}$ have the same inductance value. Also, the capacitors $C_{1}, C_{2}$ have the same capacitance value. In the case of ZSC, the output part is composed of the switch $S$, the low pass filter $L_{f}-C_{f}$, and the load resistance $R_{0}$.

ZSC has two operation modes; state 0 and state 1 . During the term of state 0 , the switch $S$ is on. The Z-source inductors $L_{1}, L_{2}$ are magnetized, and the capacitors $C_{1}, C_{2}$ of Z-source are discharged. During the state 1 cycle,

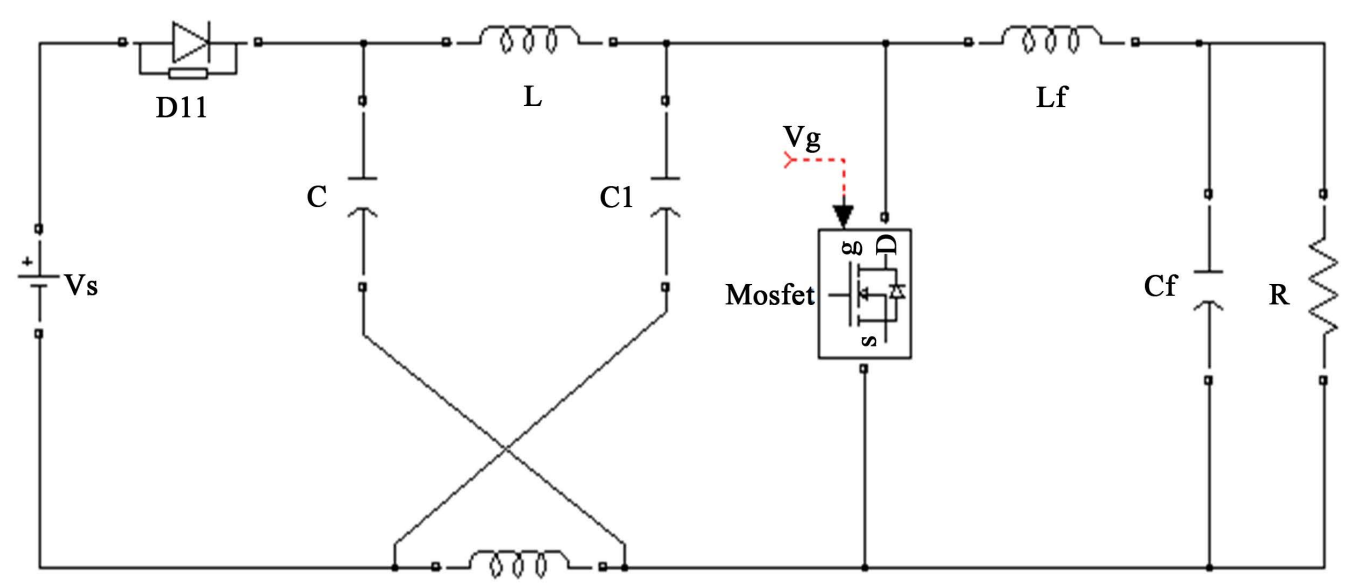

L1

Figure 1. Voltage-fed Z-source DC-DC converter. 
the switch $S$ is off. The Z-source inductors $L_{1}, L_{2}$ and input voltage source $V_{\text {in }}$ provide the energy to the output part and the Z-source capacitors $C_{1}, C_{2}$. By repeating these two operation modes, ZSC can output positive polar boost voltage. The equivalent circuits and the associated expressions corresponding to different stages of operation of the PWM Z-source dc-dc converter in CCM, the dc input-to-output voltage conversion factor and minimum inductance required to ensure CCM operation for power losses in the components of the PWM Z-source dc-dc converter and the overall efficiency, output voltage ripple across the filter capacitor and experimental results to validate the theoretical analysis [3]. Z-Source dc-dc converter used in applications like solar and fuel cell with high voltage gain and low ripple input current.

\section{Open Loop Quasi Z-Source Converter}

In common with Z-source network, quasi-Z-source network has both the current-fed topology and the voltagefed topology. This paper focuses on voltage-fed power conversion circuit which is shown in Figure 2. In analogy with Z-source network, the dc-dc converter output part can be added to quasi-Z-source network, and quasiZ-source network can be applied to the dc-dc converter. ZSC has some disadvantages; the discontinuity of input current, high voltage stress on Switch is more. The $L_{f}-C_{f}$ output filter is used to smoothen the output current and load voltage respectively.

To overcome the above problems of ZSC, quasi-Z-source converter is proposed in [3]. Quasi Z-source converter has an LC impedance network, which is the improved Z-source network. The operation of qZSC is similar to the opeartion of ZSc, along with the advantages of Z-source network topology, quasi-Z-source network has some advantages, such as continuous input current, low voltage stress on capacitors, and sharing the input and output grounds. In common with Z-source network, quasi-Z-source network can be applied to dc-dc power conversion. Quasi-Z-source dc-dc converter (qZSC) is proposed in [4]. Along with the advantages of ZSC, qZSC has the above advantages of quasi-Z-source network. Also, the voltage gain of qZSC is the same as that of ZSC.

\section{Modes of Operation}

qZSC has two operation modes, state 0 and state 1 . During the term of state 0 , the switch $s$ is on and the diode $D_{1}$ is off. The inductor $L_{1}$ is magnetized by the input voltage source $V_{\text {in }}$ and the capacitor $C_{2}$. Also, the inductor $L_{2}$ is magnetized by the capacitor $C_{1}$. During the term of State 1 , the switch is off and the diode $D_{1}$ is on. The input voltage source $V_{i n}$ and the inductor $L_{1}, L_{2}$ provide the energy to the load resistance $R_{0}$. Moreover, the capacitor $C_{1}$ is charged by the input voltage source $V_{\text {in }}$ and the inductor $L_{1}$, and the capacitor $C_{2}$ is charged by the inductor $L_{2}$. By repeating these two operation modes, qZSC can boost the voltage.

1) State $0\left(t_{o} \leq t \leq t_{o n}\right)$ when the switch is $\mathrm{ON}$.

During the term of state 0 , the switch $s$ is on and the diode $D_{1}$ is off. The inductor $L_{1}$ is magnetized by the input voltage source $V_{\text {in }}$ and the capacitor $C_{2}$. Also, the inductor $L_{2}$ is magnetized by the capacitor $C_{1}$.

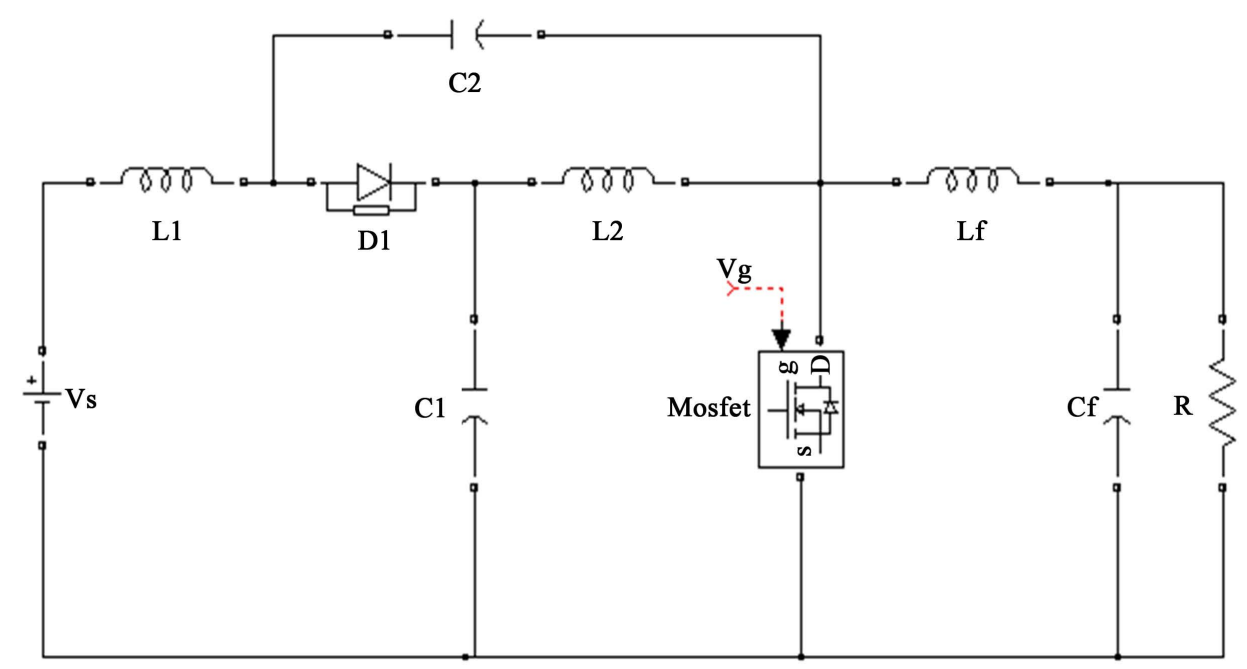

Figure 2. Voltage-fed quasi Z-source DC-DC converter. 
As shown in Figure 3, the following equations are derived in state 0 .

$$
\begin{gathered}
V_{i n}+V_{L_{1}}+V_{C_{2}}=0 \\
V_{C_{2}}+V_{L_{2}}=0 \\
V_{C f}=V_{0}
\end{gathered}
$$

2) State $1\left(t_{o n} \leq t \leq t_{\text {off }}\right)$ when the is switch OFF.

During the term of State 1 , the switch is off and the diode $D_{1}$ is on. The input voltage source $V_{\text {in }}$ and the inductor $L_{1}, L_{2}$ provide the energy to the load resistance $R_{0}$. Moreover, the capacitor $C_{1}$ is charged by the input voltage source $V_{i n}$ and the inductor $L_{1}$, and the capacitor $C_{2}$ is charged by the inductor $L_{2}$.

As shown in Figure 4, the following equations are derived in state 1.

$$
\begin{gathered}
V_{\text {in }}+V_{L_{1}}-V_{C_{2}}=0 \\
V_{L_{2}}=V_{C_{2}} \\
V_{C_{1}}+V_{L_{2}}+V_{L_{f}}=V_{0}
\end{gathered}
$$

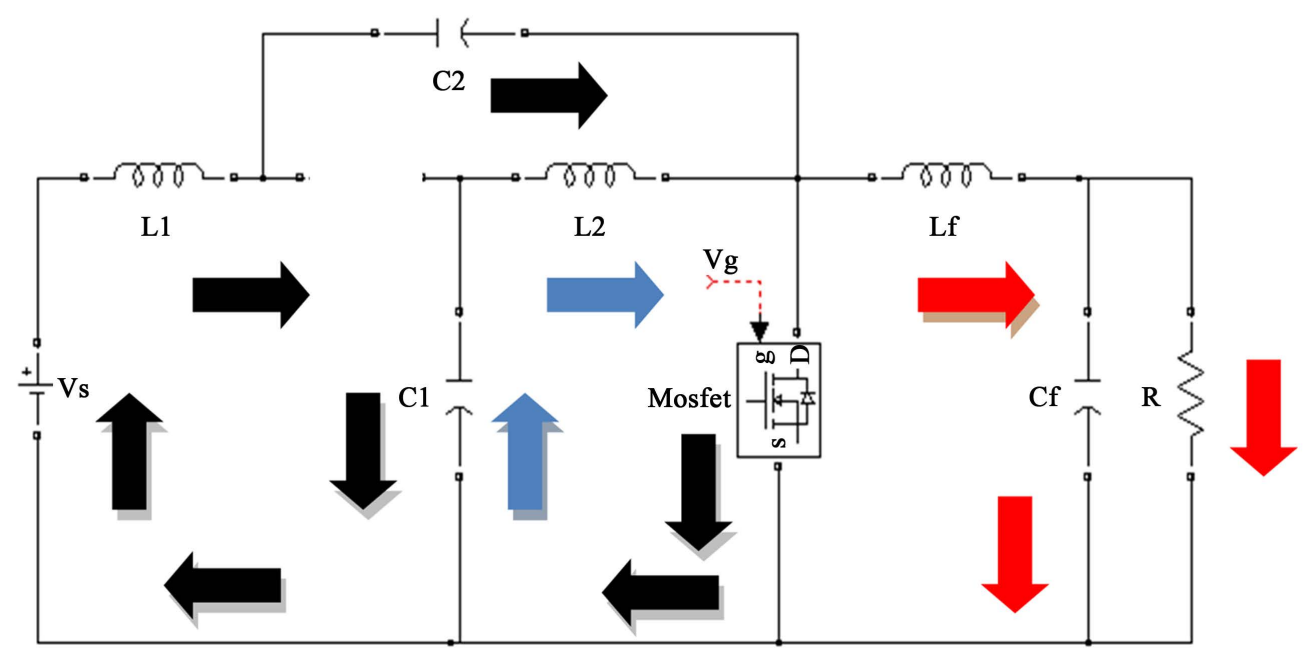

Figure 3. Quasi Z-source DC-DC converter when the switch on.

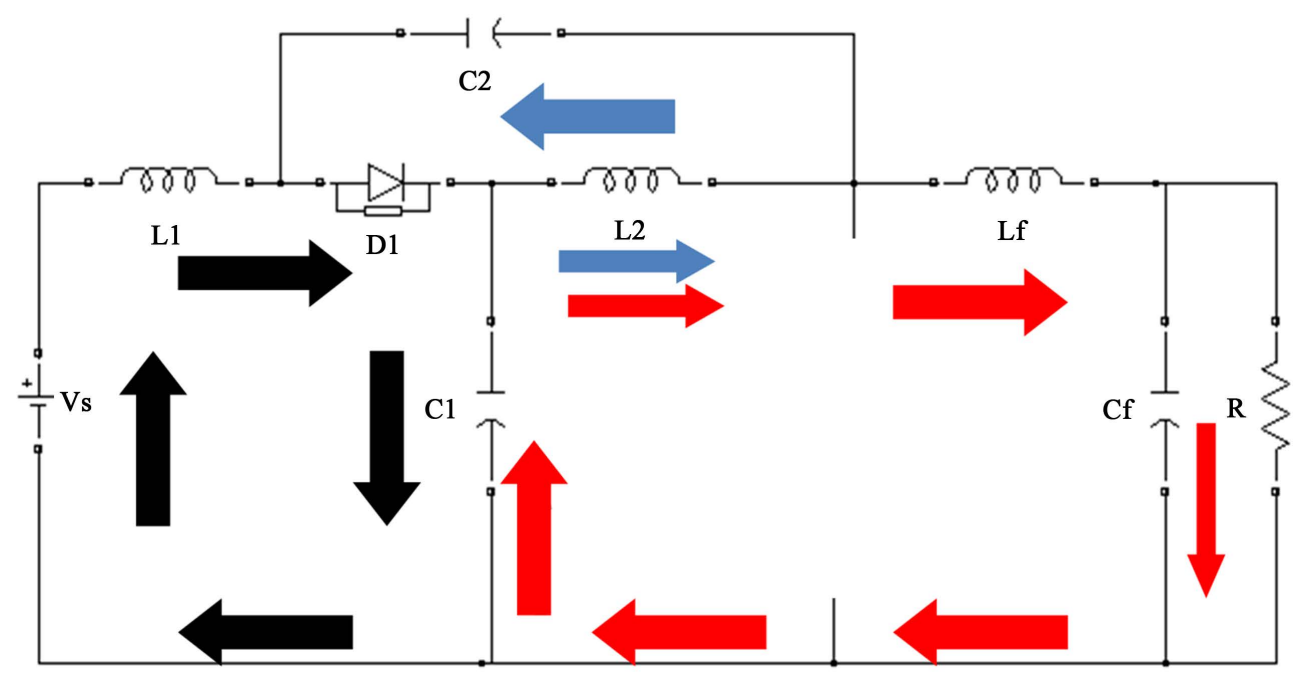

Figure 4. Quasi Z-source DC-DC converter when the switch off. 
$D$-duty ratio.

$T_{s}$ - total time period.

$T_{\text {on }}$ - switch ON period.

$T_{\text {off }}$ switch OFF period.

Where $V_{\text {in }}$ is the supply voltage.

$V_{C_{1}}$ is the capacitor $C_{1}$ voltage.

$V_{C_{2}}$ is the capacitor $C_{2}$ voltage.

$V_{C_{f}}$ is the filter capacitor $C_{f}$ voltage.

$V_{L_{1}}$ is the voltage across the inductor $L_{1}$.

$V_{L_{2}}$ is the voltage across the inductor $L_{2}$ with reference to Figure 2.

$$
\begin{gathered}
T_{\text {ON }}=D T_{S} \\
T_{\text {off }}=(1-D) T_{S}
\end{gathered}
$$

where $D$-duty ratio.

$T_{S}$ - total time period.

$T_{\text {on }}$ - switch ON period.

$T_{\text {off }}$ switch OFF period.

In steady-state, the averaged voltages of $L_{1}, L_{2}$ are zero for one switching cycle $T_{S}$. Therefore, the following equations are satisfied.

$$
\begin{aligned}
& \frac{1}{T_{S}}\left[\int_{t_{0}}^{t_{o n}} V_{L_{1}} \mathrm{~d} t+\int_{t_{\text {on }}}^{t_{\text {off }}} V_{L_{1}} \mathrm{~d} t\right]=0 \\
& \frac{1}{T_{S}}\left[\int_{t_{0}}^{t_{\text {on }}} V_{L_{2}} \mathrm{~d} t+\int_{t_{\text {on }}}^{t_{\text {off }}} V_{L_{2}} \mathrm{~d} t\right]=0
\end{aligned}
$$

Substitute (1) and (4) in (9)

$$
\frac{1}{T_{s}}\left[\int_{t_{0}}^{t_{o n}}\left(-V_{\text {in }}-V_{c_{1}}\right) \mathrm{d} t+\int_{t_{o n}}^{t_{\text {off }}}\left(V_{c_{1}}-V_{\text {in }}\right) \mathrm{d} t\right]=0
$$

Substitute (2) and (5) in (10)

$$
\frac{1}{T_{s}}\left[\int_{t_{0}}^{t_{o n}}\left(-V_{c_{1}}\right) \mathrm{d} t+\int_{t_{o n}}^{t_{\text {off }}}\left(V_{c_{2}}\right) \mathrm{d} t\right]=0
$$

Since the voltages across $C_{1}, C_{2}$, increase and decrease linearly in two operation modes, the averaged voltages $V_{c_{1}}, V_{c_{2}}$, across $C_{1}, C_{2}$, are expressed as follows in steady state.

$$
\begin{aligned}
& V_{c_{1}}=\frac{1}{T_{0}} \int_{t_{0}}^{t_{\text {on }}}\left(V_{c_{1}}\right) \mathrm{d} t=\frac{1}{T} \int_{t_{\text {on }}}^{t_{\text {off }}}\left(V_{c_{1}}\right) \mathrm{d} t \\
& V_{c_{2}}=\frac{1}{T_{0}} \int_{t_{0}}^{t_{\text {on }}}\left(V_{c_{2}}\right) \mathrm{d} t=\frac{1}{T} \int_{t_{\text {on }}}^{t_{\text {off }}}\left(V_{c_{2}}\right) \mathrm{d} t
\end{aligned}
$$

Substitute (7), (8), (13) and (14) in (11) we will get

$$
V_{c_{2}}=\left[V_{c_{1}}(1-D)-V_{\text {in }}\right] / D \text {. }
$$

Substitute (7), (8), (13) and (14) in (12) we will get

$$
V_{c_{2}}=\frac{V_{c_{1}} D}{(1-D)} \text {. }
$$

Equating Equations (15) and (16) we will get

$$
V_{c_{2}}=\frac{V_{i n}(1-D)}{(1-2 D)} .
$$


In steady-state, the averaged voltages of $L_{f}$ are zero for one switching cycle $T_{S}$. Therefore, the following equations are satisfied.

$$
\frac{1}{T_{s}}\left[\int_{t_{0}}^{t_{o n}}\left(V_{L f}\right) \mathrm{d} t+\int_{t_{o n}}^{t_{\text {off }}}\left(V_{L f}\right) \mathrm{d} t\right]=0
$$

Substitute (3), (6) in (18) we will get

$$
V_{0}=\left[V_{\text {in }}(1-D) / 1-2 D\right] .
$$

In steady-state, the input power is equal to output power

$$
\begin{gathered}
P_{i n}=P_{0} \\
I_{L_{1}}=\frac{I_{0}(1-D)}{(1-2 D)} .
\end{gathered}
$$

The ripple Current allowed to the inductance

$$
\Delta I_{L}=I_{L} * \delta \%
$$

$\delta$-allowed Ripple.

\section{PI Controller Design}

Smart Control is a general-purpose controller design software specifically for power electronics applications. To design the controller of a dc-dc converter with a single control loop using the Smart Control software. Before going to Smart control find bode plot of the Plant. The converter selected in this example is a quasi Z-source converter with voltage model control, as shown in Figure 5. The voltage regulator to be designed is highlighted in the red box. Before going to the design define the converter and Select the sensor, regulator type, crossover frequency and phase margin. Given a particular design, the attenuation given by the sensor and the regulator at the switching frequency is calculated and displayed in the edit box $|\mathrm{K}(\mathrm{s}) * \mathrm{R}(\mathrm{s})|$ at Fsw. The PI controller parameters are shown in Table 1.

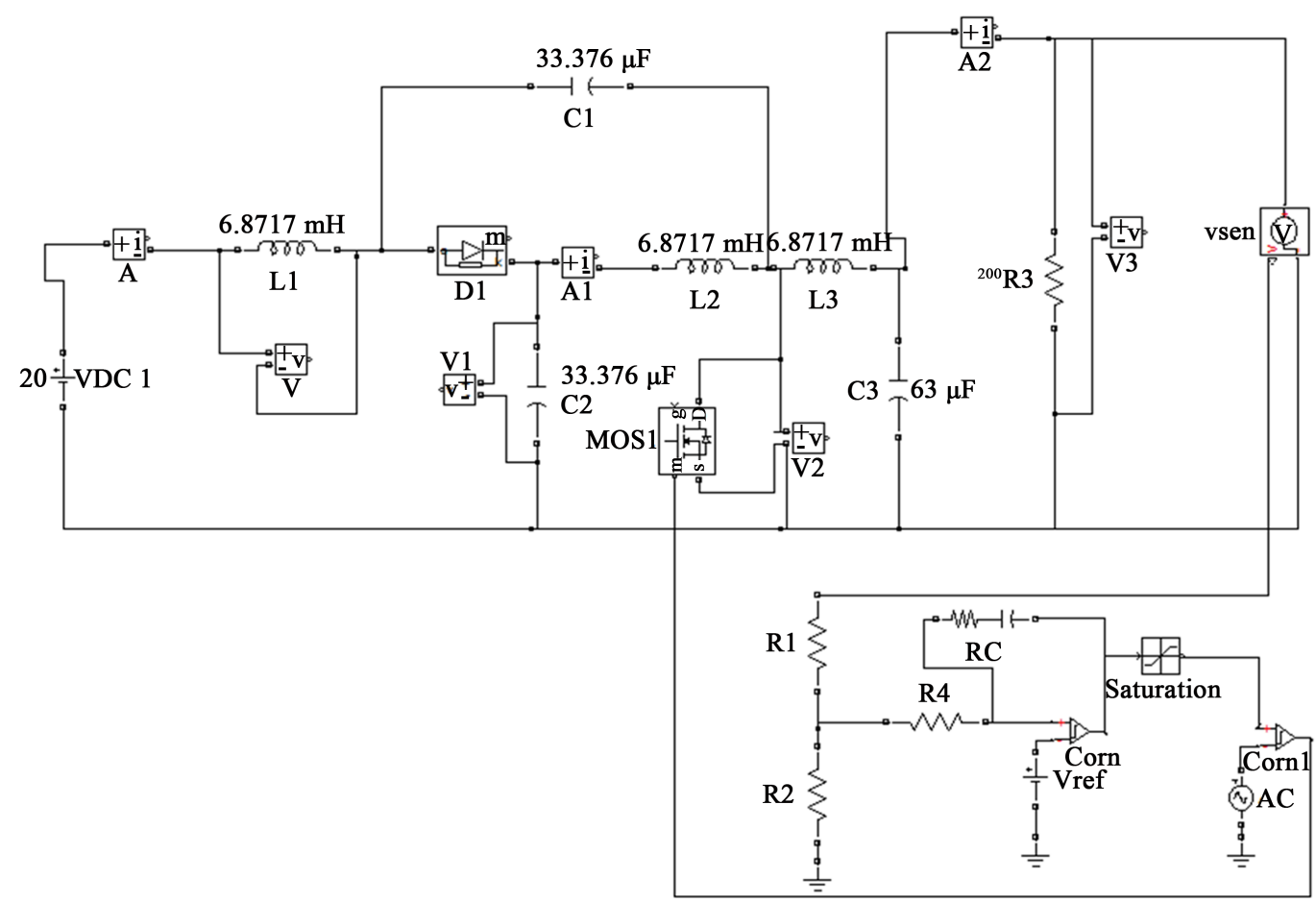

Figure 5. Quasi Z-source DC-DC converter closed loop controlled circuit diagram. 
Note that if there is not enough attenuation at the switching frequency, the system will likely oscillate in the high frequency region. Also, if a design is not proper, the edit boxes will be change to the red color, warning users to re-select the design. After the design is completed, Smart Control provides the component values for the sensor and the regulator.

\section{Simulation Results}

In this paper the simulation model is developed with Psim software. The simulation is carried out for closed loop control of converter shown in Figure 3. The simulation circuit of proposed method and output waveform is shown in figure below. The proposed converter has to boost the voltage from $20 \mathrm{~V}$ to $120 \mathrm{~V}$ with the switching frequency $f_{s}=20 \mathrm{kHz}$ and load Resistance $R_{0}=200 \Omega . V_{\text {in }}$ and $V_{0}$ are the input and output voltage while $I_{\text {in }}$ and $I_{0}$ are the input and output current which are all positive. The Gating Pulses, Voltage across the switch and the current through MOSFET switch is shown in Figure 6. Figure 7(a) and Figure 7(b) shows the capacitor voltage $C_{1}$ and $C_{2}$ of qZSC. Current through inductor of $L_{1}$ and $L_{2}$ of qZSC is shown in Figure 8(a) and Figure 8(b). Figure 9 and Figure 10 shows the output voltage and current of closed loop control. On the other hand Figure 11 and Figure 12 shows the output voltage and current of losed loop control when there is a change in load. The circuit parameters are listed in Table 2.

As observed from Figure 11 and Figure 12, whenever there is load change, the closed loop control action maintains the output voltage at desired value, whereas the current decreases due to increase in load resistance. Hence proposed closed loop control helps in regulating load voltage during load variation.
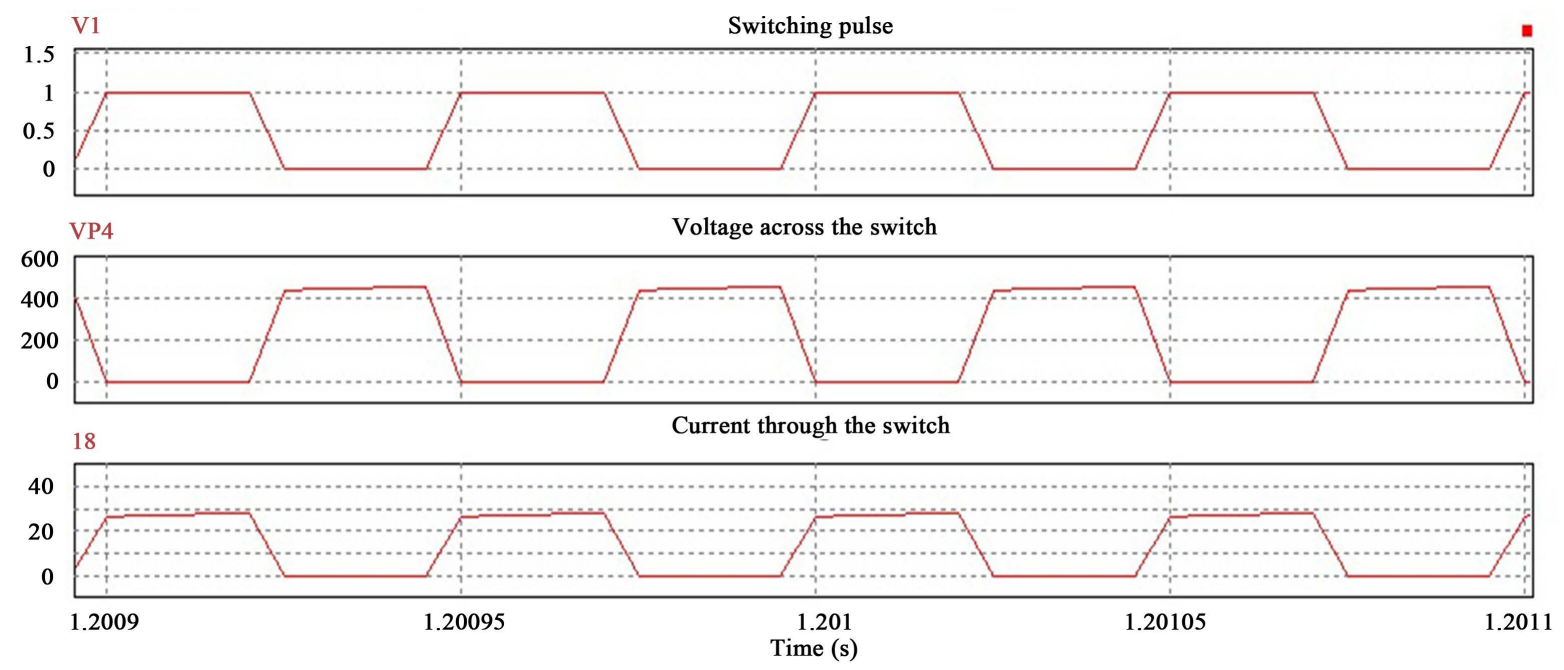

Figure 6. Gating pulses, voltage across the switch and the current through the switch.

Table 1. PI controller parameters.

\begin{tabular}{ccc}
\hline Component & Values \\
\hline$f_{s w}$ & $20 \mathrm{kHz}$ & $23.5 \mathrm{~K} \Omega$ \\
$R_{a}$ & $500 \Omega$ & $2.5 \mathrm{~V}$ \\
$R_{b}$ & $87.752 \mathrm{~K} \Omega$ \\
$V_{\text {ref }}$ & $10 \mathrm{~K} \Omega$ \\
$R_{2}$ & $24.5036 \mathrm{nF}$ \\
$R_{11}$ & 0.2 \\
$C_{2}$ & $G_{\text {mod }}$ & \\
\hline
\end{tabular}




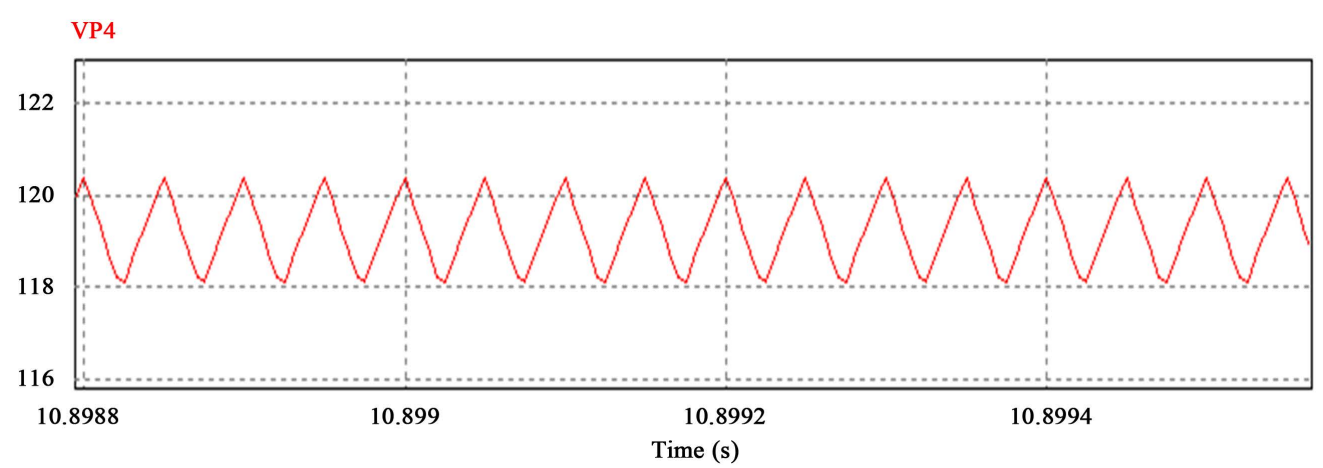

(a)

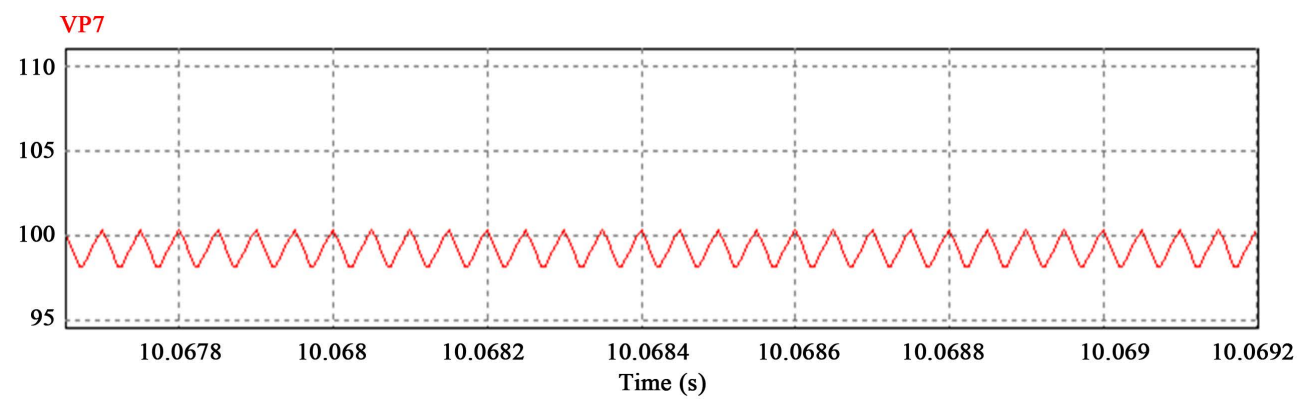

(b)

Figure 7. (a) Quasi Z-source DC-DC converter capacitor voltage $C_{1}$; (b) Quasi Z-source DC-DC converter capacitor voltage $C_{2}$.

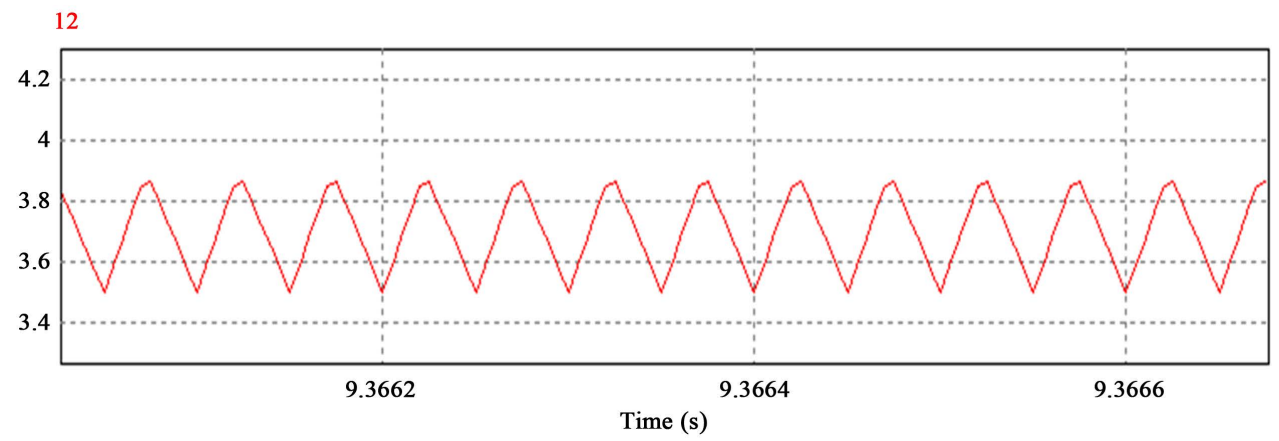

(a)

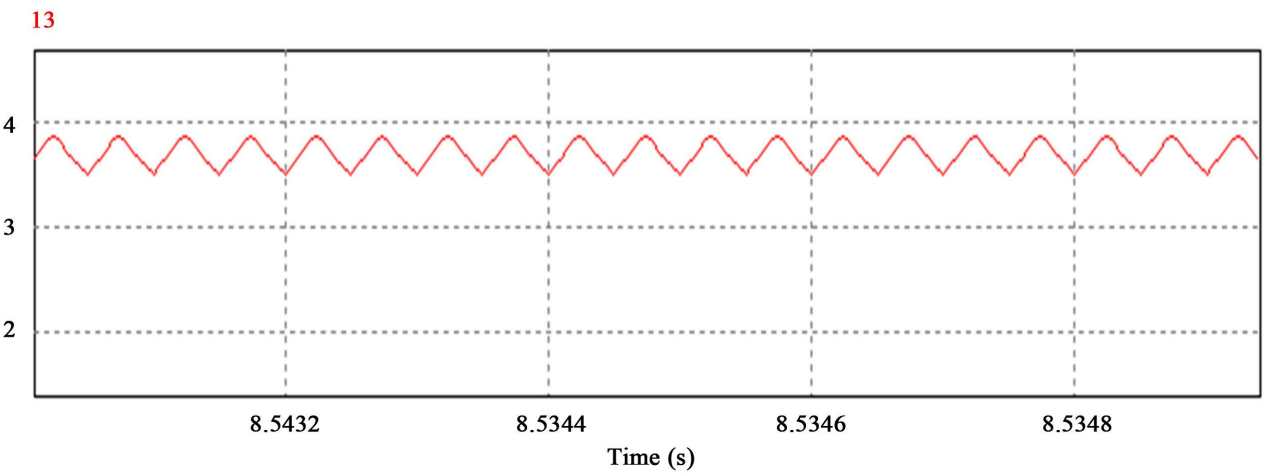

(b)

Figure 8. (a) Quasi Z-source DC-DC converter inductor current $L_{1}$; (b) Quasi Z-source DC-DC converter inductor current $L_{2}$. 


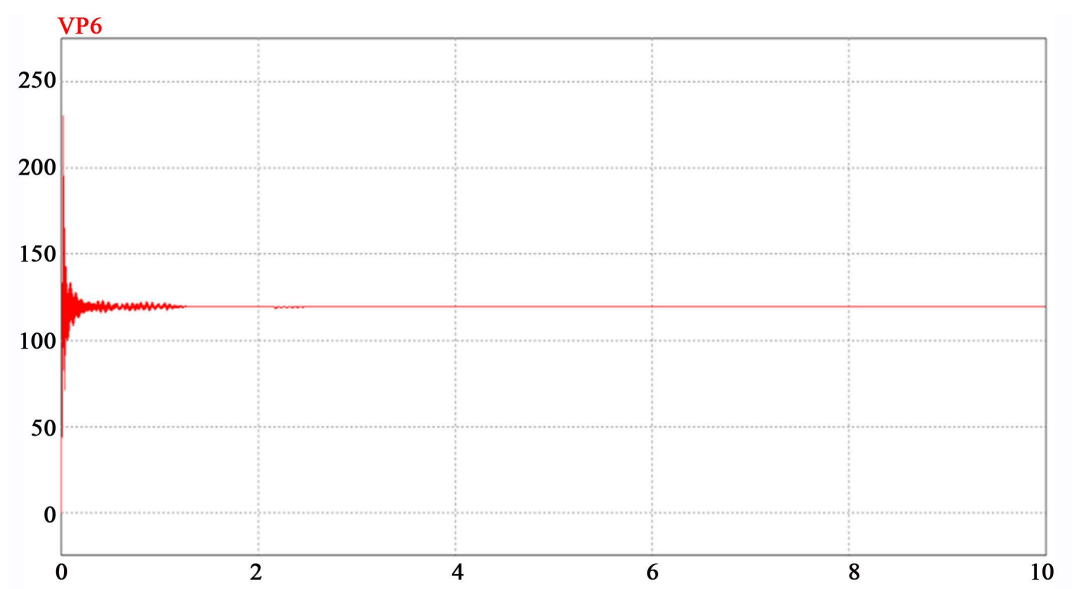

Figure 9. Closed loop controlled output voltage.

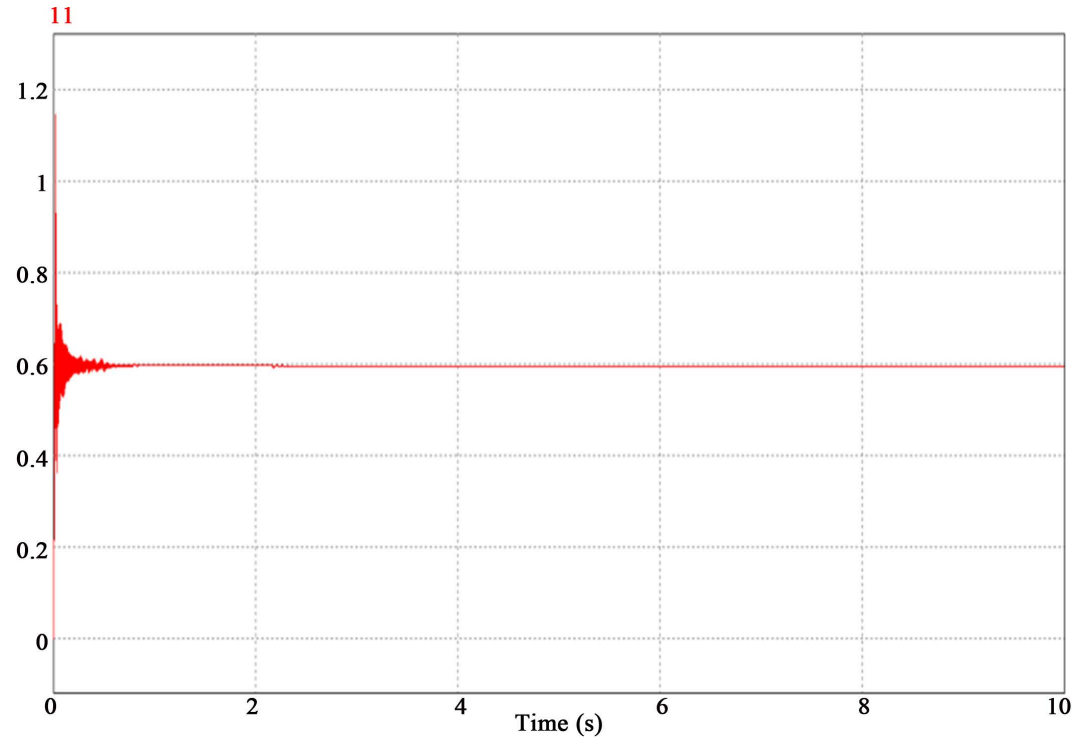

Figure 10. Closed loop controlled output current.

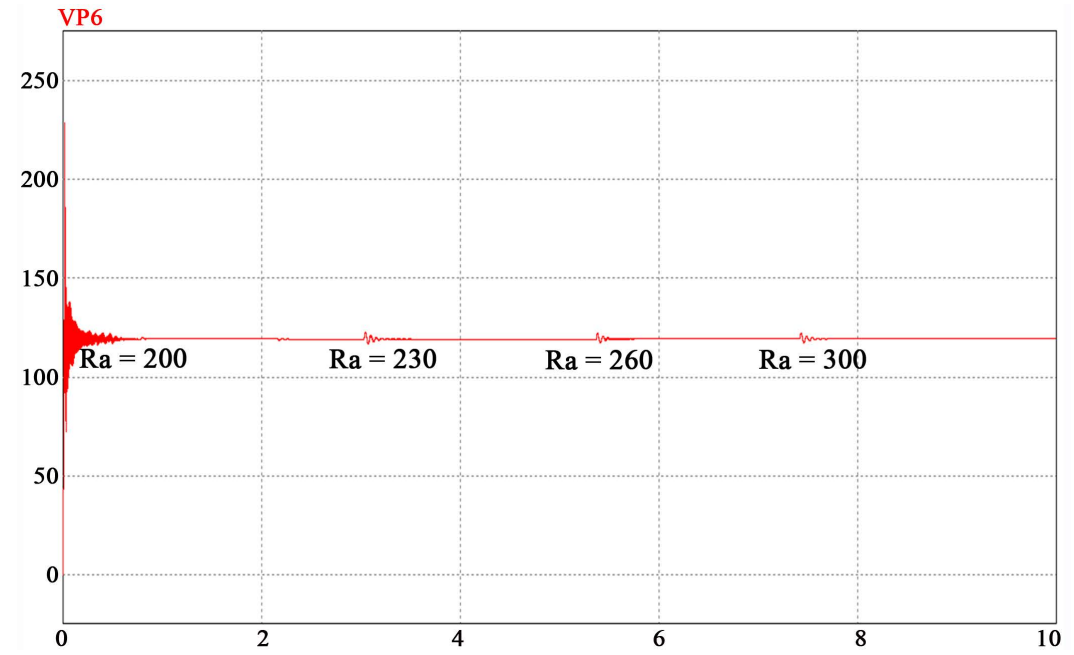

Figure 11. Closed loop controlled output voltage while change in load. 


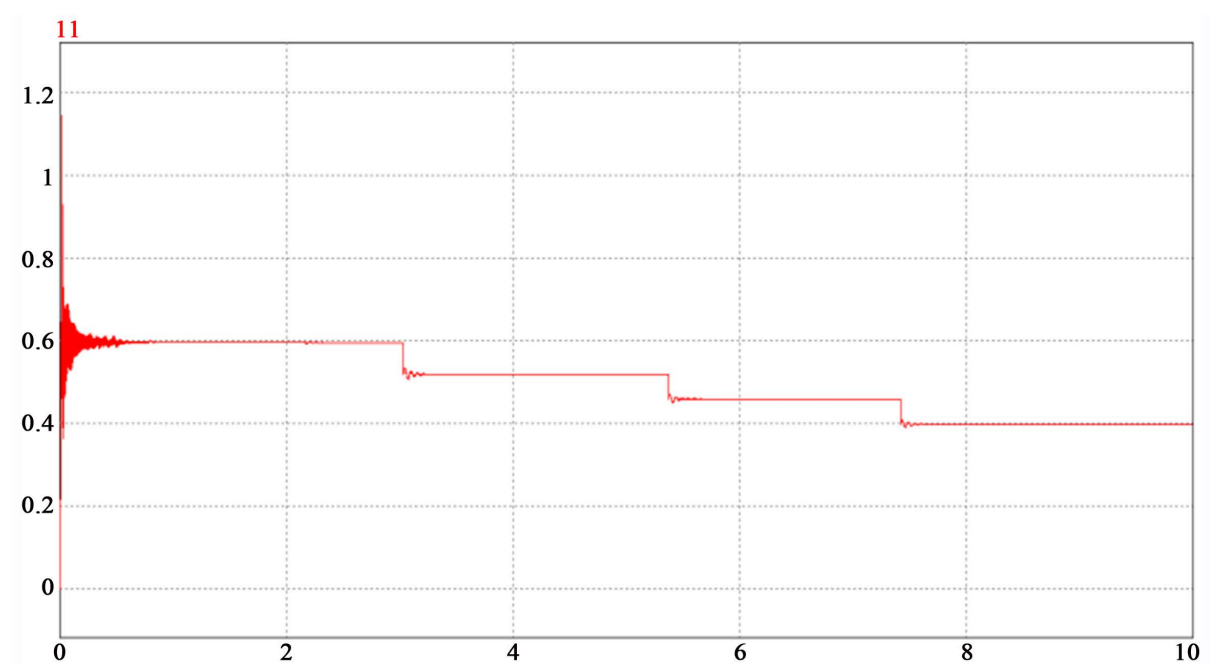

Figure 12. Closed loop controlled output current while change in load.

Table 2. Circuit parameters.

\begin{tabular}{ccc}
\hline & Component & Values \\
\cline { 2 - 3 } Quasi Z-source network & Inductor $L_{1}$ & $6.8717 \mathrm{mH}$ \\
& Inductor $L_{2}$ & $6.8717 \mathrm{mH}$ \\
& Capacitor $C_{1}$ & $33.763 \mu \mathrm{F}$ \\
Low passfilter & Capacitor $C_{2}$ & $33.763 \mu \mathrm{F}$ \\
\hline & Inductor $L_{f}$ & $6.87 \mathrm{mH}$ \\
\hline & Capacitor $C_{f}$ & $0.4815 \mu \mathrm{F}$ \\
\hline
\end{tabular}

\section{Conclusion}

In this paper, the PI controller is designed by using smart control and the closed loop control performance of quasi Z-source dc-dc converter was analyzed for step change in load. By PWM duty ratio control, it can boost the input voltage. It can reduce cost and improve reliability. Quasi-Z-source dc-dc converter has been proposed with low pass filter. The quasi Z-source converter draws continuous current from supply and the input current ripple is also less compared to Z-source converter. By the circuit analysis and experiment, the operation of the proposed circuit has been confirmed.

\section{References}

[1] Peng, F.Z. (2003) Z-Source Inverter. IEEE Transanction Industrial Application, 39, 504-510. http://dx.doi.org/10.1109/TIA.2003.808920

[2] Peng, F.Z., Joseph, A. and Wang, J. (2005) Z-Source Inverter for Motor Drives. IEEE Transactions on Power Electronics, 20, 857-863. http://dx.doi.org/10.1109/TPEL.2005.850938

[3] Gajanayake, C.J. and Blaabjerg, J. (2007) Z-Source Inverter Based Power Quality Compensator with Enhanced RideThrough Capability. Proceedings of EEE Industry Applications Conference, 42nd IAS Annual Meeting: Conference Record, New Orleans, 23-27 September 2007, 955-962. http://dx.doi.org/10.1109/07ias.2007.148 
[4] Fang, X. (2008) A Novel Z-Source dc-dc Converter. Proceedingof IEEE International Conference on Industrial Technology, 1-4.

[5] Anderson, J. and Peng, F.Z. (2008) Four Quasi-Z-Source Inverters. Proceedings of IEEE Power Electronics Specialists Conerence, Rhodes, 15-19 June 2008, 2743-2749. http://dx.doi.org/10.1109/pesc.2008.4592360

[6] Anderson, J. and Peng, F.Z. (2008) A Class of Quasi-Z-Source Inverters. Proceedings on IEEE Industry Applications Society Annual Meeting, Edmonton, 5-9 October 2008, 1-7. http://dx.doi.org/10.1109/08ias.2008.301

[7] Cao, D. and Peng, F.Z. (2009) A Family of Z-Source and Quasi-Z-Source dc-dc Converters. Proceedings of IEEE Applied Power Electronics Conference, Washington DC, 15-19 February 2009, 1093-1101. http://dx.doi.org/10.1109/apec.2009.4802800

[8] Ioinovici, A. (2001) Switched-Capacitor Power Electronics Circuits. IEEE Circuits and Systems Magazine, 1, 37-42. http://dx.doi.org/10.1109/7384.963467

[9] Wang, J., Dunford, W.G. and Mauch, K. (1998) Some Novel Four-Quadrant DC-DC Converters. Proceedings on Power Electronics Specialists Conference, Fukuoka, 17-22 May 1998, 1775-1782. http://dx.doi.org/10.1109/PESC.1998.703422

[10] Mohan, N., Underland, T.M. and Robbins, W.P. (2003) Power Electronics Converter, Applications and Design. John Wiley \& Sons, Inc.

[11] Berkovich, Y. and Ioinovici, A. (2008) Switched-Capacitor/Switched-Inductor Structures for Getting Transformerless Hybrid dc-dc PWM Converters. IEEE Transactions on Circuits and Systems I: Regular Papers, 55, 687-696. http://dx.doi.org/10.1109/TCSI.2008.916403

[12] Jiao, Y., Luo, F.L. and Wang, F. (2011) Voltage-Lift-Type Switched-Inductor Cells for Enhancing dc-dc Boost Ability: Principles and Integrations in Luo Converter. IET Power Electronics, 4, 131-142. http://dx.doi.org/10.1049/iet-pel.2010.0021

[13] Rashid, M.H. (1993) Power Electronics Handbook. Prentice Hall, Englewood Cliffs.

[14] Zhu, M., Wang, T. and Luo, F.L. (2011) Analysis of Voltage-Lift-Type Boost Converters. 7th IEEE Conference on Industrial Electronics and Applications, Singapore, 18-20 July 2012, 214-219.

[15] Raveendran, A., Paul, E. and Ommen, A.P. (2015) Quasi Z-Source DC-DC Converter with Switched Capacitor. Journal of Engineering Research and General Science, 3, 1132-1137. 